\section{EVALUATION ON DISCOMFORT LEVEL AMONG STUDENTS USING DESKS IN CLASSROOMS}

\author{
Mahmood Alia,e*, Mohd Sapuan Salita,b, Karmegam Karuppiahc, \\ Abu Saleh Ahmedd
}

aLaboratory of Biocomposite Technology, Institute of Tropical Forestry and Forest Products, Universiti Putra Malaysia, 43400 UPM Serdang, Selangor, Malaysia.

bDepartment of Mechanical and Manufacturing Engineering, Universiti Putra Malaysia, 43400 UPM Serdang, Selangor, Malaysia. cDepartment of Environmental and Occupational Health, Faculty of Medicine and Health Sciences, Universiti Putra Malaysia, 43400 UPM Serdang, Selangor, Malaysia.

dDepartment of Mechanical and Manufacturing Engineering, Universiti Malaysia Sarawak, 94300 Kota Samarahan, Sarawak, Malaysia.

eDepartment of Mechanical Engineering, Polytechnic Kuching Sarawak, KM.22, Jalan Matang, 93050 Kuching Sarawak.
Article history

Received

30 July 2015

Received in revised form

30 September 2015

Accepted

31 October 2015

*Corresponding author: mode_intan@yahoo.com

\section{Graphical abstract}

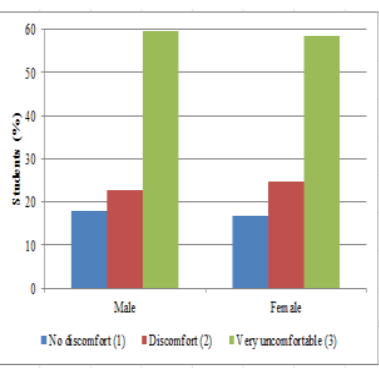

\begin{abstract}
This study was conducted to evaluate the discomfort level among students using desks in classrooms of Polytechnic Kuching. The students $(n=500)$ completed the questionnaire survey form using Borg's CR-10 Scale showing body chart discomfort. The students was asked to identify their body areas experiencing discomfort and to rate this discomfort on a score rating groups (0 to 5). Score 0-1.99= No discomfort (1), score 2.00-3.99= Discomfort (2) and score 4.00-5.00 = Very uncomfortable (3). The evaluation of the seating shows discomfort level of students and any outstanding problems arising. Students were asked to rank in the order of 10 statements about comfort and choose three responses which gave the most consistent equal interval scale. The results in that the main response of discomfort indicated the students mostly agree that they are feeling from cramped, stiff, numb, sore and tender to unbearable pain, barely comfortable and feel uncomfortable. The project was identified to evaluate the comfort level of classrooms desks for polytechnic students. Overall, there was a significant discomfort level for the students whilst using the desks and a possible solution put forward is to design a new type of classroom desk made of natura fibre reinforced composite.
\end{abstract}

Keywords: Evaluate comfort level, Classroom desks, Polytechnic students.

\begin{abstract}
Abstrak
Kajian ini dijalankan untuk menilai tahap ketidakselesaan di kalangan pelajar menggunakan meja di dalam kelas Pengajian Politeknik Kuching. Pelajar-pelajar $(n=500)$ melengkapkan bentuk soal selidik menggunakan Borg CR-10 Skala menunjukkan badan rasa tidak selesa carta. Pelajar-pelajar telah diminta untuk mengenal pasti bidang badan ketidakselesaan mengalami mereka dan untuk mengadar ketidakselesaan ini pada kumpulan Kedudukan skor (0-5). Skor 0-1,99 = Tiada rasa tidak selesa (1), skor 2,00-3,99= Ketidakselesaan (2) dan skor 4,00-5,00 = Sangat tidak selesa (3). Penilaian duduk menunjukkan tahap ketidakselesaan pelajar dan sebarang masalah yang timbul. Pelajar diminta untuk pangkat dalam perintah 10 kenyataan tentang keselesaan dan pilih tiga
\end{abstract}

